\title{
Open Access and A2K: Collaborative Experiences in Latin America
}

\author{
Nancy Gómez
}

E-LIS Editor for Argentina, LLAAR discussion list coordinator

Teaching Assistant, Universidad Carlos III, Madrid, Spain

and

Paola C. Bongiovani

Researcher and faculty member at Universidad Nacional de Rosario, Argentina

Consultant at Ministerio de Ciencia, Tecnología e Innovación Productiva de Argentina - technical point person for the "Federated Network of Institutional Repositories of Scientific Documentation in Latin America" Project

LLAAR discussion list coordinator

\section{Introduction}

Today, information is at the heart of all economies. Modern societies must keep pace with the growth of knowledge. This has become crucial for sustainable development. But, it is also important to note that restrictions exist with regard to accessing knowledge, with large numbers of people in the world who are being left behind in terms of having access to knowledge. It is critical to overcome these barriers in any possible way. While the Internet and digital technologies facilitate access to knowledge, at the same time there are certain barriers that prevent access. An alternative way to restore the lost equilibrium is the development of resources that favor open access to knowledge.

In this chapter the access to knowledge (A2K) movement is based on definitions coined by theorists Benkler (2006), Balkin (2010) and Shaver (2007), who advance the concept of human development and equal access to knowledge as distributive justice. This chapter focuses on the role of Latin American countries in the WIPO development agenda and the role of library associations against excessive intellectual property regulations which impose barriers to access and ultimately the creation of new knowledge. The concepts of A2K to Open Access (OA), showing how OA can restore knowledge as a public good on a global scale, are also discussed in this chapter. 
The chapter also provides an account of the growth of global OA, portrays the Latin American situation and takes into account OA indicators from Argentina, Chile and Brazil. It also reports on international and regional projects, describing several collaborative projects developed in the region. The results of a survey to members of the LLAAR ${ }^{1}$ discussion list are presented. Finally, the chapter arrives at conclusions that integrate the concepts of A2K, OA, collaborative work, and development and growth of Open Access in the region.

\section{Access to Knowledge (A2K)}

The A2K movement focuses on enhancing human capabilities to access, use and contribute to (create) knowledge. The concept follows the human development paradigm as articulated by economist Amartya Sen (Shaver 2007) where the goal of economic development is that all human beings can enjoy fundamental capabilities. Therefore, knowledge is considered a primary good of crucial value for human wellbeing, beyond the inevitable cultural and individual diversity regarding what kind of knowledge is valuable (Shaver 2007). Jack Balkin (2010) defines the A2K movement as a set of public policies and private initiatives that encourage growth, dissemination and sharing of knowledge around the world. A2K is a matter of distributive justice, as it seeks to provide equal opportunities in different countries and their societies. Yochai Benkler (2006) identifies different types of "knowledge" for the purposes of A2K.

The first type involves information-embedded goods, such as vaccines and software, which require scientific or technical knowledge for their creation. The second type refers to information-embedded tools, used to create knowledge and information-embedded goods, including scientific research methods, the Internet, and other communication technologies. A third type deals with information like data, scientific outputs and news. The fourth type entails human knowledge, i.e. attained education, specific abilities and expertise as well as tacit knowledge. Facilitating broad access and the use of each of these types of knowledge will promote the development and freedom of human beings (Benkler 2006; Balkin 2010).

One of the difficulties the A2K movement tries to overcome has to do with intellectual property laws. At present, intellectual property (IP) regulations create barriers to A2K. This is a universal policy issue of our time. In 2004, stemming from the discontent of public interest groups on IP, governments from Argentina and Brazil raised a proposal to the World Intellectual Property Organization (WIPO). They succeeded in creating what is known as a "development agenda” with a focus on non-proprietary approaches (NON IP) 
based on creative innovation models such as open source software and open genome research.

Both Kapczynski (2008) and Fernandez Molina (2008) highlight the role played by Argentina and Brazil in this matter. To lend support to their proposal, a meeting was organized in Geneva, Switzerland which was attended by politicians and business representatives, along with participants with interests in areas such as access to low cost medicines, free software, the Creative Commons, open science and open edition campaigns. The participants at the meeting produced a document entitled the "Geneva Declaration on the Future of the World Intellectual Property Organization". Signatories postulated that "the world is facing a crisis in the governance of knowledge, technology, and culture", with an emphasis on copyright barriers. The document reported on the lack of access to low cost medicines, global inequities in access to education and technology, obstacles to continued growth in innovation, the progressive expropriation of the public domain and a concentration of anti-competitive knowledge industries.

The declaration was signed by 493 individuals, 61 signatures from Latin Americans (12\%) and 7 institutional representatives, led by the International Federation of Library Associations and Institutions (IFLA), and four library associations from the United States: the American Library Association (ALA), the Special Libraries Association (SLA), the American Association of Law Libraries (AALL) and Association of Research Libraries (ARL). The remaining two signatures were from Doctors Without Borders and Consumers International (CI).

The document was sent to other countries, and, as a result, twelve other countries were added. Fourteen countries, including eight from Latin America (Argentina, Bolivia, Brazil, Cuba, the Dominican Republic, Ecuador, Peru and Venezuela); six from Africa (Egypt, Iran, Kenya, Sierra Leone, South Africa and Tanzania) formed the group that became known as "The Group of Friends of Development” (FOD) (Fernandez Molina 2008). The group has held a number of meetings, with no substantial results thus far.

The signing of this declaration by IFLA and the American Library Association emphasizes the role of libraries as knowledge intermediaries who make every effort to provide equal access to information. Their signatures also indicate that libraries see their responsibility as suppliers and guardians of access to information as a public good (Pessach 2007). IFLA showed its commitment to the issue from the beginning. Moreover, Ellen Tise, IFLA president, 2009-2011, chose the theme "Libraries Driving Access to Knowledge" as the critical strategy for this association during her tenure in office (Tise 2008).

In addition, the NGO Consumers International (www.consumers international.org/our-work/copyright), in support of the Geneva Declaration, has issued two reports since 2009, known as the Intellectual Property (IP) 
Watchlist reports. The reports evaluate how balanced a country's copyright laws are; they review whether the laws are applied in ways that affect consumer interests; and, whether the country promotes the exchange of knowledge in ways that are not subject to exclusive rights. This work was done through a survey, which includes sixty criteria that were developed and weighed by international experts. This report is taken into account when analyzing the situation in Latin America.

As it is commonly known, modifications of international policy-making processes are lengthy and time consuming. For this reason, institutions and non-government agencies are taking steps, according to their abilities, to question IP regulations, challenge barriers and offer some strategies toward the A2K movement, such as Open Access and Open Source.

Developing countries have raised these issues before WIPO, because they can express more openly their unequal access to medicines, information and other issues that are regulated by over-protective intellectual property laws that give developing countries few advantages. This harks back to the concept of distributive justice as advanced by Benkler (2006) and to Ellen Tise (2008) who said that "knowledge generation is essential to the process of development”.

\section{$\mathrm{A} 2 \mathrm{~K}$ and $\mathrm{OA}$}

One of the most advanced initiatives to promote access to knowledge is the OA movement that makes it possible to restore the commons approach without changing national or international laws (Benkler 2006). In 2002, the Budapest Open Access Initiative defined open-access as follows:

"The literature that should be freely accessible online is that which scholars give to the world without expectation of payment. Primarily, this category encompasses their peer-reviewed journal articles, but it also includes any unreviewed preprints that they might wish to put online for comment or to alert colleagues to important research findings. There are many degrees and kinds of wider and easier access to this literature. By 'Open Access' to this literature, we mean free availability on the public internet, permitting any users to read, download, copy, distribute, print, search, or link to the full texts of these articles, crawl them for indexing, pass them as data to software, or use them for any other lawful purpose, without financial, legal, or technical barriers other than those inseparable from gaining access to the internet itself. The only constraint on reproduction and distribution, and the only role for copyright in this domain, should be to give authors control over the 
integrity of their work and the right to be properly acknowledged and cited” (Budapest Open Access Initiative 2002).

Verschraegen and Schiltz (2007) propose that the OA movement creates the conditions for knowledge and science to be regarded as global public goods, which meet the criteria for non-rival and non-excludable consumption (Stiglitz 1999). The mere use of knowledge or information in digital format does not diminish its availability to others, but it is possible, by technological or legal means, to prevent the use of these assets.

OA, by eliminating those barriers, restores the potential for knowledge to be a universal common good. OA to knowledge can be regarded as a key ingredient in developing strategies to improving access to information in developing countries (Verschraegen and Schiltz 2007).

Two complementary strategies exist to reach OA: the golden route, which is publishing in OA journals; and, the green route, where the scholarly literature is deposited in OA repositories (BOAI 2002). For both strategies there are open source software packages which are free of cost and customizable which is common in the A2K movement.

Libraries and librarians around the world, equipped with the necessary technical skills to provide quality metadata and other value-added services, are taking the lead in this field, by taking responsibility for the creation of institutional repositories. Most importantly, they are placed in the right position to serve as mediators between academic authors, publishers and end users seeking access to academic literature (McKay 2007).

OA initiatives in developing countries provide the means for them to make their own research more visible and, at the same time, to gain access to research that is produced in other countries (Suber and Arunachalam 2005). OA presents a real opportunity to correct many of the inequalities and injustices inherent in the knowledge barriers that stand between the nations that are referred to as "core” and "peripheral” (Guédon 2007).

\section{Growth of OA}

Heather Morrison reported on the dramatic growth of OA (Morrison 2005). In February 2005, approximately 1,400 OA journals were registered in the Directory of Open Access Journals (www.doaj.org); and, in August 2010, that number had climbed to 5,300. Morrison reported that the OAIster (www. oclc.org/oaister) database of Open Access resources included 5 million records. According to OCLC, that number had increased to 25 million records in 2010, representing digital resources 
The increase in the number of repositories and Open Access journals can be seen in the following chart, where it looks like the two strategies are showing growth in absolute values.

\begin{tabular}{l|c|c}
\hline Year & $\begin{array}{c}\text { Number of Repositories } \\
\text { (ROAR) }\end{array}$ & $\begin{array}{c}\text { Number of Journals } \\
\text { (DOAJ) }\end{array}$ \\
\hline 2006 & 792 & 2,514 \\
\hline 2007 & 968 & 3,031 \\
\hline 2008 & 1,239 & 3,812 \\
\hline 2009 & 1,557 & 4,535 \\
\hline 2010 & 1,798 & 5,140 \\
\hline
\end{tabular}

Table 1: Growth of OA in ROAR and DOAJ

A recent study by Bo-Christer Björk and colleagues of peer-reviewed journal articles published in 2008, found that approximately $20 \%$ of the articles were freely available online, with differences in the scientific fields (Björk et al. 2010). Earth sciences had the highest availability of OA articles (25.9\% green and $7 \%$ gold), physics and astronomy had most of their OA share (20.5\%) available through the green route, with only $3 \%$ published in OA journals. Chemistry and chemical engineering had the lowest availability of OA articles (7.4\% green and 5.5\% gold). In medicine, biochemistry and related fields, the most prevalent form of OA was via OA journals (golden road), whereas, in other fields, posting the author's manuscript in repositories or other sites was the prevailing method.

Studies showing OA citation advantage are gathering momentum. These studies verify the number of citations received by a document that has unrestricted access. Free access to the full text of articles has been proven as one of the factors influencing the likelihood for a document to be accessed, read and cited (Hajjem, Harnard and Gingras 2005; Moed 2007; Norris, Oppenheim and Rowland 2008; Davis 2008; Gargouri et al. 2010).

Lawrence (2001), one of the pioneers of this line of work, investigated and demonstrated that highly cited articles in computer science corresponded to works that were freely available on the Web. Later, other authors (Hajjem 2005 and Kurtz 2005) observed the same phenomenon in other subject areas such as physics and astrophysics. Studies by other authors show the opposite, for example, in Condensed Matter Physics (Moed 2007) and Conservation Biology (Calver and Bradley 2010) there was no evidence of citation increase due to OA. Currently, the topic is the subject of several analyses and studies 
aimed at clarifying the effects on impact and visibility of research outputs when they are released free of access barriers.

Even when the advantages of OA are demonstrated, what matters in terms of advancing towards a hundred percent research literature availability is changing authors' behavior. OA mandates are the keys that encourage authors to archive their works in repositories. Authors do not diligently provide content to repositories unless they are required to do so by their research funders. A study by Alma Swan (2006) found that most authors (81\%) said they would comply with a mandate willingly, and $14 \%$ said they would comply reluctantly. According to Harnad (2010) the experience with mandates that are in place shows that this is true.

Indicators, including sustained growth of repositories and OA journals, as well as a rising number of bibliometric studies, show an increasing interest from scientific communication researchers in the topic. OA is growing and it is here to stay.

\section{The Latin American Situation}

OA in Latin America has advanced unevenly, with differences across countries. For the purpose of a more specific, comparative follow-up of OA growth in the region, this work examines the situation in three countries - Argentina, Brazil and Chile - which has already been analyzed in a previous work (Gómez et al. 2009). The studied indicators in the abovementioned work are updated here, showing a growth of OA indicators in all three countries. This analysis also considers other aspects, such as interventions of Latin American countries in WIPO, as well as the Consumers International IP Watchlist Report (2010) which ranks the studied countries among the 10 worst rated with respect to access to information.

A description of the situation with regard to Information and Communication Technology (ICT) is provided as a starting point. This is followed by an examination of cooperative regional and international projects because they introduce a binding element in the advancement of OA. Next, the description of the indicators that were taken for comparison is shown in a table of comparative values. And finally, a description of each country, based on the specified parameters is provided.

Concerning ICT, a description of the status of the basic infrastructure needed to deliver ICTs is essential to provide an overview of countries within the Information Society. The World Summit on the Information Society (WSIS), whose main goal is to promote the conditions to build an information society and narrow the digital divide, has created the Digital Opportunity Platform (International Communication Union 2007). This is an open and multistakeholder platform, with contributions from governments, intergovernmental 
organizations, as well as academics and the civil society. Within this platform, WSIS developed an assessment tool, the Digital Opportunity Index (DOI), made up of eleven indicators grouped into three categories:

1. Opportunity (percentage of population covered by mobile cellular telephony, Internet access, and mobile cellular tariffs, as a percentage of per capita income);

2. Infrastructure (proportion of households with a fixed telephone line, a computer, Internet access at home, mobile cellular subscribers per 100 inhabitants, mobile internet subscribers per 100 inhabitants); and the

3. Use of Communication Technologies (proportion of individuals that used the internet, ratio of fixed broadband subscribers to total internet subscribers, ratio of mobile broadband subscribers to total mobile subscribers).

The DOI index was used by Gómez et al. (2009) to describe the evolution of DOI in Latin American countries between 2004 and 2006. They found that most countries had improved their DOI indicator with Chile, Argentina, and Brazil appearing to be taking the first places. It is important to point out that Shaver (2007) also included the DOI index in his outline of an Access to Knowledge Index.

Alperin et al. (2008) also studied the ICT infrastructure with data from Nielsen NetRatings and they reported that between 2000 and 2008 Internet usage worldwide had grown by approximately $275 \%$, while in Latin America it had grown by $600 \%$. But even with such dramatic growth, population penetration is still low, only about $21 \%$, according to the author. This means that with respect to ICT distribution and usage there is much untapped potential. There is also an opportunity for further progress towards the Information Society as well as the opportunities that this brings for a more fluid exchange of information and knowledge.

\section{Collaborative Projects Advancing OA}

Other elements that create the foundations for expanding OA in the region are international, regional and group projects that have developed recently. With regard to international projects, NECOBELAC (Network of Collaboration between Europe \& Latin American-Caribbean countries www.necobelac.eu/en/ index.php) is a three year project (2009-2011) funded by the European Commission under the 7th Framework Program on Science and Society. This project is involved in public health promotion, seeking to improve scientific writing, to support OA publication models and to encourage technical and scientific cooperation among European, Latin American and Caribbean countries. 
In terms of regional projects, there are two which have been started recently. The first one is the Inter-American Development Bank's Regional Public Goods Program (www.iadb.org/topics/government/rpg/about_rpg.cfm?lang $=$ en). This finances the project "Formation of a Federated Network of Institutional Repositories Scientific Documentation in Latin America ${ }^{2}$." The project, started in June 2010, has as its aim an agreed strategy for the construction and maintenance of a federated network of institutional repositories of scientific publications, sharing and giving visibility to scientific outputs, thereby contributing to the scientific and technological development in Latin America, under a framework of agreements on interoperability and information management (Banco Interamericano de Desarrollo 2010). Participating countries are Argentina, Brazil, Chile, Colombia, Ecuador, Mexico, Peru and Venezuela through their National Research and Education Networks (NRENs) and National Science and Technology Organizations, with the coordination of the Latin American Cooperation of Advanced Networks (CLARA).

The second regional project, also started in 2010, is the CoLaBoRa (Latin American Community of Digital Libraries and Repositories http://sites. google.com/site/redlatrep1/redlatrep1/]). This project is funded by the Latin American Cooperation of Advanced Networks (CLARA) with the purpose of consolidating regional efforts and providing a single platform for unrestricted online access to academic, cultural and research production in Latin America, thereby increasing the visibility and presence of Latin American authors and institutions on the Web.

A very promising tool called Intelligo (www.explora-intelligo.info) is being developed by de Ibero-American Observatory of Science, Technology and Society, a unit of the Organization of Ibero-American States for the Education, Science and Culture (OEI). Intelligo provides a new way of searching and browsing scientific information, interacting with concept maps and accessing documents from Ibero-American repositories.

Additionally, in 2009, the Greenstone User Group in Latin America was created. Greenstone is an open source software package for the creation of digital libraries and repositories. Members of this group represent five centers in the following countries:

- Argentina (Facultad de Humanidades y Ciencias de la Educación, Universidad Nacional de La Plata; and, Facultad de Ciencias Exactas y Naturales, Universidad Nacional de Buenos Aires);

- Chile (Universidad Cardenal Silva Henríquez; and, Fundación para la Innovación Agraria); and

- Cuba (Centro de Cibernética Aplicada a la Medicina).

2 For information about the Project visit www.iadb.org/projects/project.cfm?id=RGT1684\&lang=en 
The group's purpose is to promote the acceptance of Greenstone in the region, build a regional support team that includes experts and provide a regular training schedule (UNESCO 2010).

Within the promising regional collaborative initiatives, the Latin American List on Open Access and Repositories (LLAAR, http://groups.google.com.ar/ group/LLAAR) has emerged as a forum to discuss issues related to OA and to encourage the creation and maintenance of OA repositories for academic and scientific works in Latin America. The topics discussed include: strategies to encourage the creation and maintenance of OA repositories in Latin America; strategies for creating a network of Latin American repositories; the development of an infrastructure to achieve interoperable repositories nationally, regionally and globally; the creation of policies that promote scientific development; the use of OA repositories; and, the assessment of impact and visibility of intellectual works archived in OA repositories.

Librarians working on projects related to OA in Argentina and Chile started LLAAR in June 2009. Currently, LLAAR has more than 300 members, predominantly from the Latin American region.

Wiki Acceso Abierto (Wiki AA) (http://wikiaa.unr.edu.ar) emerged in response to a need in the LLAAR community. Throughout the world, there are excellent initiatives, programs and research activities that promote OA, but there was a need for a website in Spanish to gather and organize this information. That was the goal of Wiki AA with the support of Universidad Nacional de Rosario in Argentina and the E-LIS (E-prints in Library and Information Science) repository. Wiki AA also has a broader aim which is to become an information guide on OA in Spanish for both scientific and academic works. In English, Wiki AA means Open Access Wiki.

E-prints in Library and Information Science (E-LIS http://eprints.rclis.org) repositories support the deposit, archiving and preservation of documents shared by the Library and Information Science (LIS) community. If LAAR or Wiki AA contributors want to share long articles they can submit them to the repository and share a link in the Wiki AA and the list. Most list and Wiki AA collaborators are librarians or persons working in library environments. Taken as cases that show the progress of OA and the relationship between OA and A2K in the region, these two initiatives will be analyzed against the results of a survey of members of the list in a separate section. The aim of the survey was to discover opportunities to improve performance, participant interest and impact.

As mentioned earlier, this work will show the growth of $\mathrm{OA}$ in the region through the Open Access Indicators (Gómez et al. 2009). These are used here for comparison, with some changes, in order to normalize the units of measurement and to prevent the distortion of results that would occur if different sources were used. Although a country's scientific production is not an indica- 
tor of OA, it appears in the table as a source of reference, to provide a quantitative view of scientific production and evolution within the selected countries.

Regarding scientific output, the previous work (Gómez et al. 2009) took the ISI Web of Science 2005 database as its source of information for 2005. In this work the SCOPUS database is used as a source corresponding to 2007 and 2009, because it covers a larger number of publications.

$\mathrm{OA}$ indicators are those numbers that show the evolution of OA along the lines of two main strategies: green and golden routes. In order to analyze the evolution of green $\mathrm{OA}$, the first indicator considered was the number of repositories registered in ROAR (Registry of Open Access Repositories http:// roar.eprints.org). This verified and eliminated duplicate repositories. A second indicator was the number of records in ROAR repositories, again, to verify and eliminate duplicates. A third indicator was the average number of records per repository (total records divided by the number of existing repositories in ROAR in each country, eliminating duplicates).

Golden OA indicators were also considered: the number of journals in the DOAJ directory (number of registered Latin American journals up to August 2010) and the number of journals in Scientific Electronic Library Online SciELO, www.scielo.org.ar (2007 and 2010). It is important to note that documents available in SciELO are also included in ROAR. Furthermore, regarding golden OA, it is important to note that there is a Network of Scientific Journals from Latin America and the Caribbean, Spain and Portugal (Redalyc). Redalyc, based in Mexico, is a portal providing OA to more than 600 scientific journals from and about Ibero-America. Many of these journals found in Redalyc are also found in SciELO. It is a major regional project in the area, but there is no comparative data because its data was not considered in the original comparison table (Gómez et al. 2009). Therefore, it is not included here.

\begin{tabular}{|c|c|c|c|c|c|c|c|}
\multicolumn{1}{c}{} & \multicolumn{2}{c}{ Country } & \multicolumn{2}{c}{ Argentina } & \multicolumn{2}{c}{ Brazil } & \multicolumn{2}{c|}{ Chile } \\
\hline \multirow{2}{*}{$\begin{array}{c}\text { Scientific } \\
\text { output }\end{array}$} & $\begin{array}{c}\text { Scientific output in } \\
\text { SCOPUS }\end{array}$ & 7 & $8,720^{*}$ & 30,745 & $39,887^{*}$ & 4,750 & $5,700^{*}$ \\
\hline \multirow{3}{*}{$\begin{array}{c}\text { Green Route } \\
\text { Indicators }\end{array}$} & $\begin{array}{c}\text { Number of repositories } \\
\text { (ROAR) }\end{array}$ & 2 & 10 & 55 & 71 & 4 & 6 \\
\cline { 2 - 9 } & $\begin{array}{c}\text { Number of records in } \\
\text { repositories (ROAR) }\end{array}$ & 2,143 & 37,356 & 346,411 & 503,334 & 11,610 & 32,353 \\
\cline { 2 - 9 } & $\begin{array}{c}\text { Average number of } \\
\text { records per IR (ROAR) }\end{array}$ & 1,071 & 3,735 & 6,298 & 7,089 & 2,902 & 5,392 \\
\hline \multirow{2}{*}{$\begin{array}{c}\text { Gold Route } \\
\text { Indicators }\end{array}$} & DOAJ journals & 42 & 70 & 287 & 472 & 81 & 111 \\
\cline { 2 - 9 } & SCIELO (August 2010) & 29 & 62 & 185 & 237 & 66 & 89 \\
\hline
\end{tabular}

Table 2: Open Access indicators for Argentina, Chile, and Brazil, with comparative values 


\section{Argentina}

Regarding scientific output, Argentina is the second of the three selected countries, producing in 2010 approximately 9,200 documents according to the SCOPUS database. This indicates a 24\% increase when compared to 2007. Argentina is the country that shows the most pronounced growth in its OA indicators. In ROAR, this country is represented by ten repositories, with a fivefold increase in the number of repositories in the directory between 2007 and 2010. While the total number of records increased 17 times and the average number of records per repository moved from 1,100 to 3,700, a $236 \%$ percent increase.

It is worth mentioning the creation of BDU2 (http://bdu.siu.edu.ar/cgi-bin/ query.pl) a portal and repository harvester developed by Consorcio SIU, a University Consortium. BDU2 harvests 15 repositories using the OAI-PMH protocol with the objective of providing a unified search interface for information resources available from Argentinean repositories, as well as national and international visibility for those outputs.

The increase of available documents and the generation of a harvesting tool show that the visibility of documents from Argentina increased substantially from 2007 to 2010, both by increasing the absolute number of available documents and by expanding on the number of tools that were developed to access these records.

Regarding golden route indicators of OA, the Directory of Open Access Journal registered 70 electronic journals from Argentina in 2010, showing a $67 \%$ increase since 2007. Argentinean representation in SciELO increased by $114 \%$ going from 29 journals in 2007 to 62 journals in 2010. It is important to note the increase in number of OA documents available in ROAR; a cause for this may be the inclusion of SciELO as a repository. Guédon (2010) explains very well the particular characteristics of SciELO when he states:

"A SciELO Journal works like a small, peer-reviewed and thematic repository that would be endowed with a title that acts like a logo (for branding purposes) and some publishing capacity, including copyediting. As a result, the ScieLO formula works toward blurring the distinction between Green and Gold Approach to Open Access”.

Likewise, CAICyT (Centro Argentino de Información Científica y Tecnológica), a branch of CONICET (Consejo Nacional de Investigaciones Científicas y Técnicas), is developing a Portal for Scientific and Technical Publications (PPCT) which promotes OA to Argentinean journals that have appropriate editorial quality and academic content, through an OJS (Open Journal System) platform. This portal is for new Argentinean scientific and technical journals, 
those have been already edited in print, or which have requested management support for their online editorial and publication process.

Argentina's Digital Opportunity Index (DOI) is 0.51 , placing this country between Chile and Brazil on this index. In October 2005, Creative Commons (http://creativecommons.org/international/ar/) licenses have been ported to local legal frameworks. If the Digital Opportunity Index (DOI) is considered, it is found that a value of 0.51 scored a second place among the three countries in 2006.

Argentinean university and research funders have not yet issued OA policies with the exception of the Universidad Nacional de Córdoba, whose Academic Affairs Secretary ruled that all knowledge produced by their institution is to be considered a public good (Universidad Nacional de Córdoba 2010).

The Ministry of Science, Technology and Productive Innovation (MINCyT) of Argentina developed a National System of Digital Repositories (SNRD) to coordinate national initiatives and to provide funds for new and existing repositories. Within the system, a draft law was proposed, requiring Argentinean agencies and public institutions that are part of the National System of Science, Technology and Innovation (SNCTI) to create OA institutional repositories to deposit their technical-scientific output and data. In addition, there is a working group whose aim is to promote OA policies and develop models of OA policies and other legal instruments to promote the growth of OA repositories. The proposed project is being discussed by Congress (Honorable Cámara de Diputados de la Nación, 2011).

Furthermore, the same Ministry is a member of the Confederation of Open Access Repositories (COAR) (http://coar-repositories.org). In 2010, this government agency organized a conference under the title "Open Science: A Regional Challenge" which presented OA initiatives under development in Argentina and Brazil and also discussed author rights in relation to repositories.

Moreover, it is possible to observe a growing concern regarding OA benefits, especially among communities of librarians in Argentina which are involved in OA policies development. The excitement shown about OA indicators is also seen in the library community with the creation of LLAAR in 2009 and Wiki AA which came later.

\section{Brazil}

Scientific production in Brazil remains the highest in the region and continues to grow from 31,000 records in 2007 to around 43,000 in 2010 (according to SCOPUS), which shows a $39 \%$ increase. According to the ROAR registry, this country has 71 repositories, showing a $29 \%$ increase in repositories registered in the directory since 2007, while the number of records increased by $45 \%$. 
During the same period, the average number of records per repository increased by $12 \%$, from approximately 6,300 to 7,100. In 2007, Brazil also had a national portal, known as Oasis.Br (http://oasisbr.ibict.br/) which harvests content from 109 repositories. It is currently out of service pending improvements.

The Directory of Open Access Journal features 472 electronic journals from Brazil, showing a 64\% increase from 2007. The Brazilian SciELO portal showed a $34 \%$ increase in the number of OA journals. Furthermore, Brazil has done a remarkable job with the implementation of its Open Journal SystemOJS, the project known as SEER, (Sistema Eletrônico de Editoração de Revistas http://seer.ibict.br/index.php) boasts 1,349 titles in its system. SEER's size is because it represents a $22 \%$ of the world's output and $79 \%$ Latin America records, compared to total journals running on OJS software. This is a significant achievement. In terms of comparison, it triples the amount of titles in SciELO. This finding is important because it suggests that Brazil is working strongly on this strategy with a great increase in 2008, adding about 700 titles that year alone (Santillan-Aldana 2010).

Brazil's Digital Opportunity Index (DOI) of 0.48 was the lowest. It was the first in the region to adopt Creative Commons licenses. At present, it is the country with the greatest number of granted licenses (Gómez et al. 2009). Brazil has advanced to accomplish the goals of OA since the creation of the SciELO platform in 1997.

The Instituto Brasileiro de Ciencia e Tecnologia (IBICT) (www.ibict.br) has taken the lead in most initiatives, coordinating actions and projects to propel the growth of the OA movement along with SciELO. This initiative was started in Brazil in 1997 by BIREME (Latin American and Caribbean Center on Health Science Information www.bireme.br) which is affiliated to PAHO (Pan American Health Organization) and WHO (World Health Organization), in partnership with FAPESP (São Paulo State Foundation for Support to Science, Brazil). IBICT is also supported by the National Science Research Council of Brazil (Packer and Meneghini 2007).

In 2005, IBICT issued the "Manifesto Brasileiro de apoio ao Acesso Livre à Informação Científica" which highlights the need to adopt a national policy with the support of the scientific community (IBICIT 2005). The same year, the Bahia Declaration on Open Access (2005) was drawn up and approved at an international conference that BIREME organized.

In 2007, IBICT participated in the creation of a Proposed Law (introduced by a member of Brazil's House of Representatives) that would require all Brazilian public institutions of higher education and research units to create OA institutional repositories to deposit their technical-scientific output. After 3 years, the project is still being discussed (Câmara dos Deputados 2010, Senado Federal 2011). 
Chile

Chile's scientific output ranks third when compared to Brazil and Argentina, showing a production of about 4,770 during 2007 and 6,213 documents (in the SCOPUS database) during 2010, representing a 30\% increase in three years. The number of repositories registered in ROAR increased by $50 \%$ between 2007 and 2010. It is worth noting that the number of records increased by $280 \%$ in the same period. Also, the average number of records per repository increased from 2,902 to 5,392 (85\%). There is no data regarding the total number of available repositories because Chile does not have a national repository portal and harvester.

With regards to OA journals, the Directory of Open Access Journal features 111 electronic journals from Chile, which represents a 37\% increase since 2007. The Chilean SciELO portal showed a 34\% increase in the number of documents, from 81 to 111 journal titles.

Among the countries surveyed, Chile has the highest Digital Opportunity Index (DOI) in Latin America, reaching 0.57. Further, Chile was the second country in the region to implement and adapt Creative Commons licenses into local legislation. This occurred in July 2005. In addition, the country is moving forward jointly with the NGO, Derechos Digitales (www.derechosdigitales. org), and the library community to raise awareness and generate materials for free content. As examples, one can mention "Editorial Policies Publications Academics in Chile" and "Legal Guide for Libraries," published by the Chilean Library Association. The latter is a technical tool to support libraries, in the face of a new intellectual property law passed in May 2010.

Derechos Digitales is one of the institutions working with Consumers International to develop an IP Watchlist. In 2010, Chile was placed last in Latin America in terms of access to knowledge. That may be related to the fact that, among the countries that have been analyzed, it is the only country that has neither signed nor supported the Geneva Declaration.

At the level of government policies, the National Scientific and Technological Research Commission (CONICYT) and the Universidad de la Frontera (UFRO) organized the international seminar "State of the Art of Scientific Research Data and Information Management Funded by Public Funds and Recommendations for the Design of a National Policy."3

The Pontificia Universidad Católica de Valparaíso plays a leading role with regards to $\mathrm{OA}$ in Chile. This university conducted a research project in order to learn how much Chilean researchers knew about OA. It also compiled a Directory of Open Access journals recognized by ISI Web of Science (http://www.ejbiotechnology.cl/proyecto/index.php).

3 http://www.conicyt.cl/573/article-36978.html 
During 2008, the same higher education institution led the eQuipu network project of Chilean journals indexed by ISI Web of Science, using OJS software as a common platform. The aim of this project is to support the work of editors and improve the quality of Chilean scientific journals by strengthening a network of professional editors, adopting higher standards in the publishing industry and consolidating on a common platform.

\section{OA Advances in the Three Countries}

The advancement of $\mathrm{OA}$ is clear and unquestionable in all three countries, with a significant increase in the two strategies (golden and green routes). There is no question that the number of records per repository is on the rise in each country, increasing by $12 \%$ in Brazil, by $85 \%$ in Chile, and by $236 \%$ in Argentina, reflecting the work that has been done to comply with the OAI protocol by institutions. It is important to highlight that these figures should be taken with some caution, because there are repositories that are not registered in ROAR. In absolute numbers, it is possible to conclude that Brazil is the most advanced, followed by Chile, whose repositories appear to be more effective in collecting content. With fewer repositories, in spite of noted growth, Argentina ranks in the last position.

When analyzed, the golden route has shown strong and sustained growth, moving from $34 \%$ to $67 \%$ in those entries registered in DOAJ, and from $34 \%$ to $114 \%$ in SciELO. Again, this last percentage indicator is higher in Argentina, which had fewer journals in the system in 2007. Brazil on the other hand, strongly supporting the golden route, with IBICT's emphasis on the SEER Project, has increased the number of journals that are available online, tripling its numbers in SciELO. While Chile shows a more regular growth while joining SciELO, one should consider that journals in the eQuipu project are mostly contained in SciELO, but running on OJS.

At the level of politics, Argentina is beginning to become aware of both pathways, which are growing steadily. In addition to awareness within the library community, Argentina is making significant progress given the short time that the project has been in existence.

Brazil apparently relied more on the golden route. It also seems to be depending on a law that would mandate that all research funded by public funds is deposited in repositories. This law is pending congressional approval. Brazil is working towards a well formulated OA policy. The approval of such policy would be very important for the rest of Latin America and the world, considering Brazil's large scientific production. Collaborative projects, both international and regional, play an essential role in this overall progress as well as in virtual communities. Swan (2008) opines that such a mandate is the way to support OA. 
Linking the growth of OA in Latin America with the role of virtual communities leads to the creation of LLAAR as a virtual collaborative space with representatives from several countries in the region. One of the benefits of such collaboration is that it is possible to learn how unresolved issues emerge in our countries and how they are linked to A2K. The following section is a discussion of Wiki AA, a virtual space that is still under construction and gathering consensus.

\section{Discussion List, Wiki and Collective Action}

As was mentioned earlier in the section devoted to collaborative projects which advance OA, the results of a survey of LLAAR members are presented here, from the point of view of growth of OA, as well as the relationship between OA and A2K. The objectives of the survey were to understand the motivation and issues of interest to LLAAR participants. In addition, the survey sought to establish the impact that participating in the list had in access to knowledge for its members and the communities where they work. The survey also aimed to identify opportunities for improvements.

Briefly, the methodology for data collection was an online survey tool. The Web address to complete the survey was sent via e-mail to the 228 members of LLAAR, during August 2010.

The questionnaire was divided into four sections: Personal Data, Benefits of Belonging to the LLAAR list (reasons for membership, covered topics and their relevance to the list of members, and the impact on the performance of their duties and professional development), Wiki AA (finding out if members visited the Wiki site, reasons for not visiting it, participation by contributing content, reasons for members not to contribute, and checking on the availability of content providers in the event that an editorial committee was created), and Concluding Remarks.

A quantitative and qualitative analysis of the data was performed.

\section{Results}

A total of 58 members of the LLAAR list completed the survey. The response rate was 25\%. Most respondents resided in Argentina (57\%), nine percent in Colombia, seven percent in Spain, five percent in Brazil and Peru, three percent in Costa Rica, Ecuador and Uruguay, two percent in Chile, Italy, Mexico and Venezuela (see Table 3). 


\begin{tabular}{l|c|c}
\hline Country & 33 & Percentage \\
\hline Argentina & 5 & $57 \%$ \\
\hline Colombia & 4 & $7 \%$ \\
\hline Spain & 3 & $5 \%$ \\
\hline Brazil & 3 & $5 \%$ \\
\hline Peru & 2 & $3 \%$ \\
\hline Costa Rica & 2 & $3 \%$ \\
\hline Ecuador & 2 & $3 \%$ \\
\hline Uruguay & 1 & $2 \%$ \\
\hline Chile & 1 & $2 \%$ \\
\hline Italy & 1 & $2 \%$ \\
\hline Mexico & 1 & $2 \%$ \\
\hline Venezuela & 58 & $100 \%$ \\
\hline Total & & \\
\hline
\end{tabular}

Table 3: Participants by Country

From the responses provided in Table 4 it is possible to see what members consider as the benefits of belonging to the LLAAR list. The responses also provide a scale of what members consider to be relevant and important to them.

Respondents were asked to indicate the reasons for their subscription to the LLAAR discussion list on a scale of importance (Table 4). The most important reason given for subscribing to the list was to keep abreast of developments relating to OA and repositories in Latin America. Responses given as "very important" and "important" represented $97 \%$ of the reasons for joining the list. The opportunity to interact with regional colleagues, who are working in libraries and other organizations in pursuit of OA, was considered "very important" and "important" by $96 \%$ of respondents. This came in as the second highest reason for joining the list.

Sharing information on progress and developments of their institutions regarding OA and repositories was regarded as "very important" and "important" (95\%). Actively participating in the dissemination and promotion of the OA movement in the region was considered "very important" and "important" (94\%).

List participants' familiarity with OA and repositories was another variable that was considered "very important" and "important" as a reason to be a member of the list. For $69 \%$ of the respondents, membership of the list al- 
lowed them to become familiar with a topic that was new to them. There were variations for this option. In contrast, $21 \%$ indicated that this reason was of "little importance" and 5\% felt that it was "not important" to them. These latter cases show that these members were already familiar with the subject.

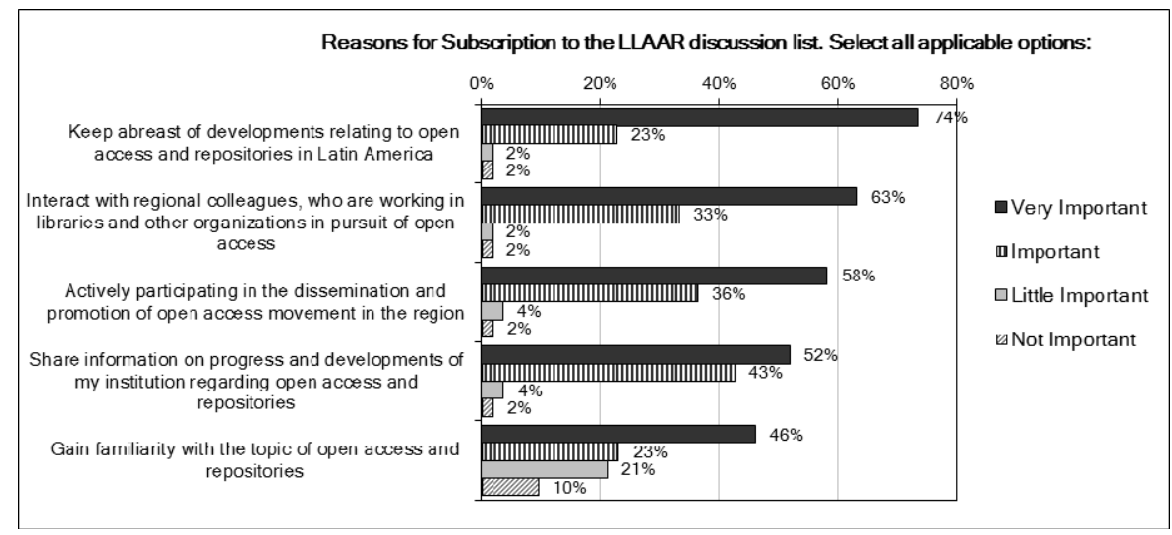

Figure 1: Reasons for Subscription to LLAAR

In addition, the survey asked members to choose the five topics that the list covered and were of greatest interest to them or to indicate other topics of interest (see Table 5). Most respondents (88\%) indicated that one of the topics of greatest interest was to learn about OA policies and mandates that were implemented in different institutions and countries. These topics have been often discussed on the list, sharing studies indicating that OA policies, specifically mandates, were the demonstrated fast tracks to OA.

As a consequence of the first topic, $72 \%$ of respondents said they were interested in discussions regarding copyright and open licenses to promote OA. One fact to bear in mind is that copyright laws in Latin America and the Caribbean, in many cases, do not provide exceptions for libraries and in some cases they include very limited exceptions (Fernández-Molina and Guimarães 2010). These two issues are related to A2K and IP barriers. As Kapczynski (2008) explained it is a recurring theme and concern among LLAAR communities. Both of these issues are the ones that create the greatest level of interaction among members.

Many respondents (70\%) expressed that one of their topics of interest was practical information about implementing repositories and OA journals. Also sixty-three percent considered it important to share and access the literature on the subject. It is interesting to note that $58 \%$ of the respondents considered that presentations on new roles for information managers were important.

Predictably, a good percentage of respondents (56\%) indicated that it was important to share information on congresses and conferences about OA and 
repositories. Fifty-one percent of respondents said they were interested in funding for OA initiatives. About $40 \%$ of the respondents said they were interested in information on workshops related to software or specific repository software packages.

A small percentage of respondents suggested other topics such as the ranking of digital repositories, integration with other tools related to libraries (catalogs, etc.), integration with digital libraries initiatives, contributions to research projects related to repositories and digital libraries management, integration with research evaluation systems (such as SIGEVA ${ }^{4}$ ), and integration with bibliographic systems.

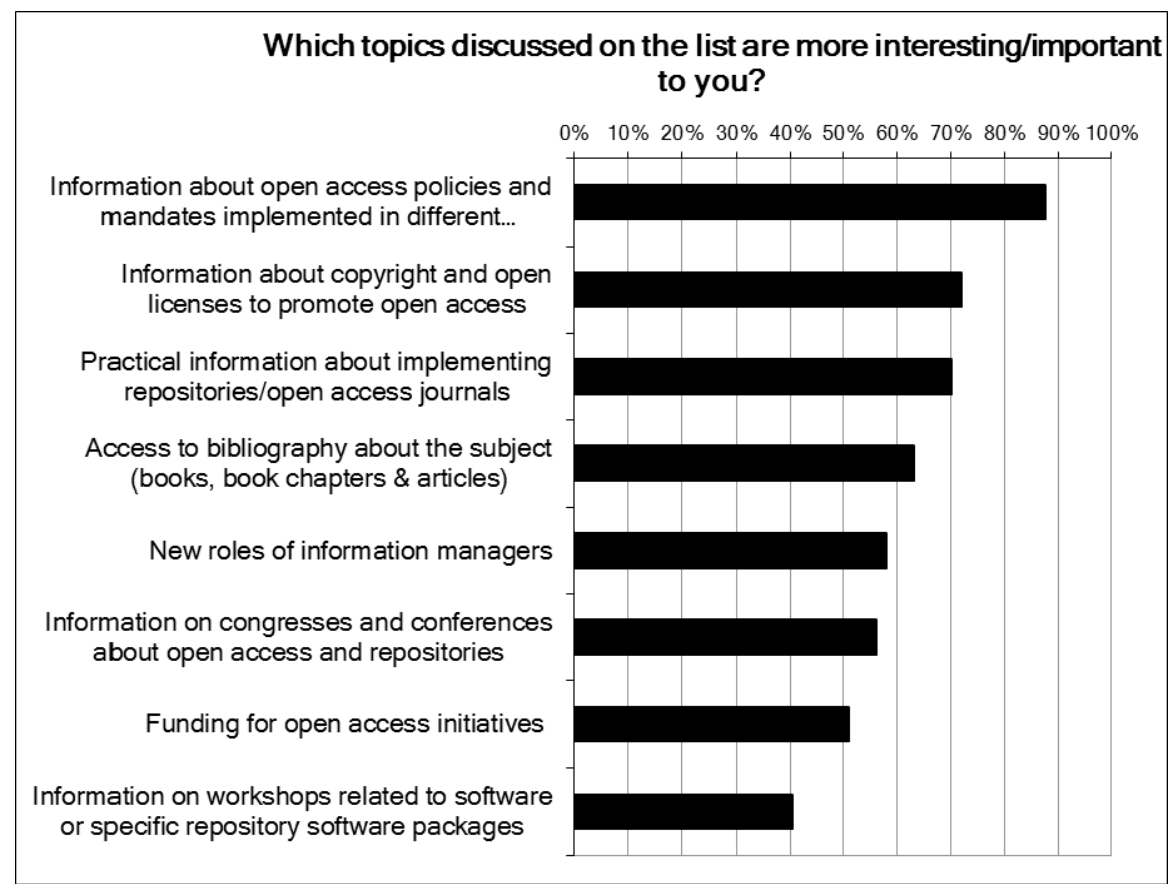

Figure 2: Topics Considered More Important

One of the most important issues the survey sought to identify was: what was the impact of participating in the LLAAR list on the professional development of its members? Options were offered describing possible ways their participation impacted on work and professional development, and respondents could choose all the options that they considered applicable to their situation (see Table 6) or add alternatives.

4 Sistema Integral de Gestión y Evaluación (SIGEVA) del Consejo Nacional de Investigaciones Científicas y Técnicas de Argentina. 
Sixty-three percent of respondents (36 respondents) felt that LLAAR membership allowed them to be more knowledgeable about the OA resources that were available and, therefore, they were able to offer them to their users. It is possible to see here a way of advancing towards access to knowledge, with librarians as intermediaries. The feeling of being part of a Latin American community of OA was a significant impact, and that option was chosen by $56 \%$ of those responding (32 respondents).

Besides, $54 \%$ of the respondents (31 respondents) considered that their membership of the list helped them communicate more effectively about the value of OA to knowledge to authorities and users within their institutions. A good number of respondents (28 respondents, 49\%) stated that being members of the list motivated them to engage and participate more actively in the management or dissemination of knowledge in their institutions.

Another impact was the ability to generate new relationships with colleagues, as expressed by $40 \%$ of the respondents (23 respondents). In addition, there was a group (19 respondents, 33\%) which considered that participating in LLAAR helped them rethink their role as librarians and information managers. These responses show a growing commitment to access to knowledge in the library community participating in LLAAR.

It is noteworthy that a $26 \%$ of the respondents (15 respondents) said that, through the list, they learned about a topic about which they knew either nothing or knew very little about. Also, the professionals answering the survey said the discussions on the list motivated them to organize events related to OA in their institutions (11 respondents, 19\%). The list is playing a role as a transmitter of contents and values of OA to knowledge to newcomers.

It is important to note that a group of respondents (10 respondents, 17.5\%) indicated that the list helped and encouraged them to propose the creation of repositories or OA journals in their institutions, which was one of the key objectives of the list. A smaller percentage of respondents (6 respondents, 10.5\%) said they found the topics discussed on the list interesting. However, LLAAR membership had no actual impact on their daily work; as a result, they had not implemented or disseminated these ideas in their professional environment. Another value of list membership, as stated by respondents, was professional development. Membership of the list motivated persons to keep abreast of the issues discussed and that they considered dissemination of knowledge for all as a strong value. 


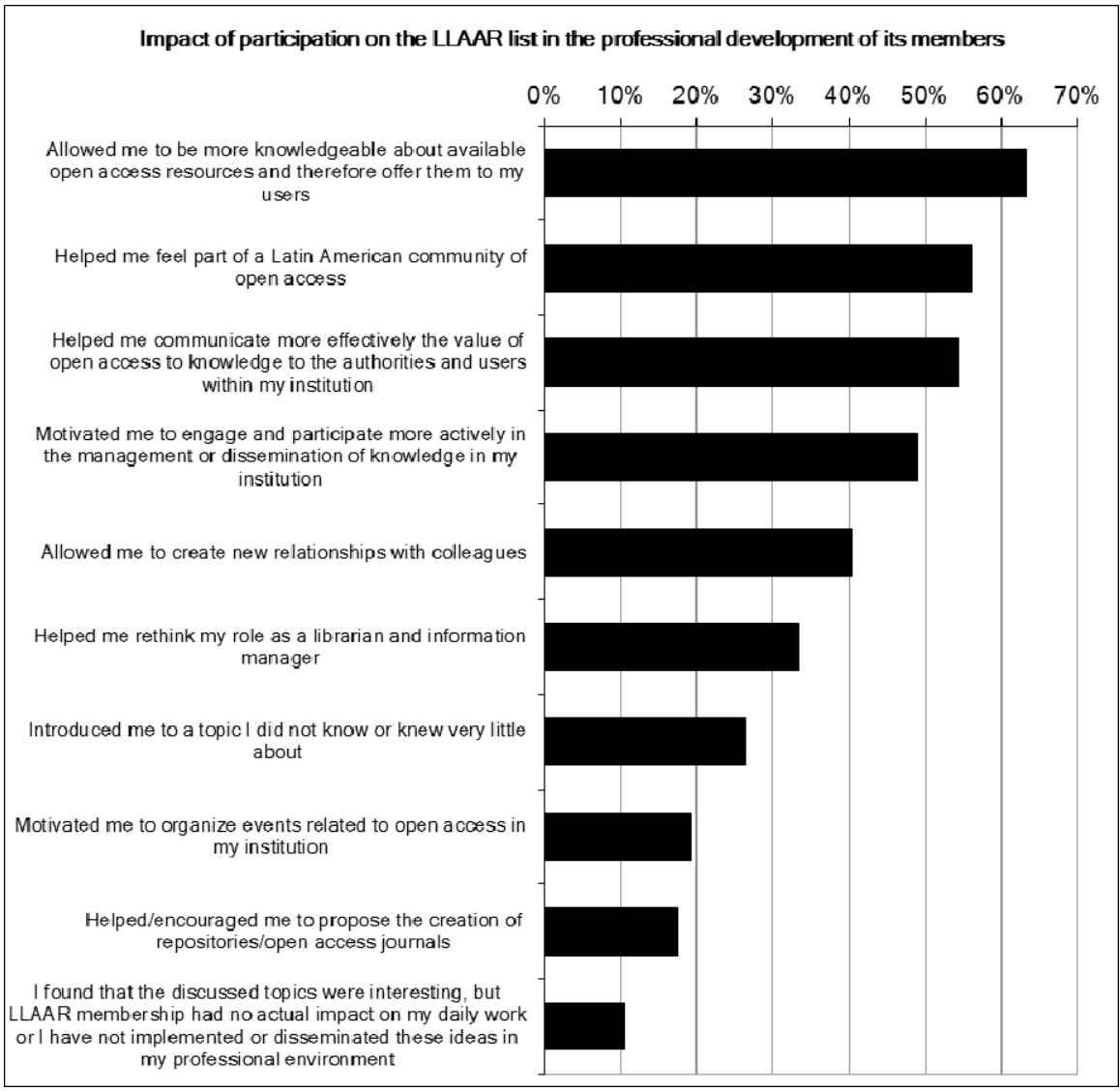

Figure 3: Impact of Participation on the LLAAR List

Regarding Wiki AA, the second initiative which is very early in its development raises the issue as if it would be easier to interact on a mailing list rather than to upload information to a Wiki. As Wiki is an emerging tool, as a consequence, it may not yet be widely used. Thus, assuming that the tool was in its initial phase, the survey asked whether respondents had visited the Open Access Wiki. A high number of respondents (27 respondents) had not visited the site; seventeen said they visited the site once, eleven said they visited the site sporadically, and three visited it regularly. The main reason for not visiting the site was unawareness of its existence (22 respondents), two respondents said they did not visit the site due to lack of time, two did not remember the site, and one respondent said that there were countless other sources of information. 


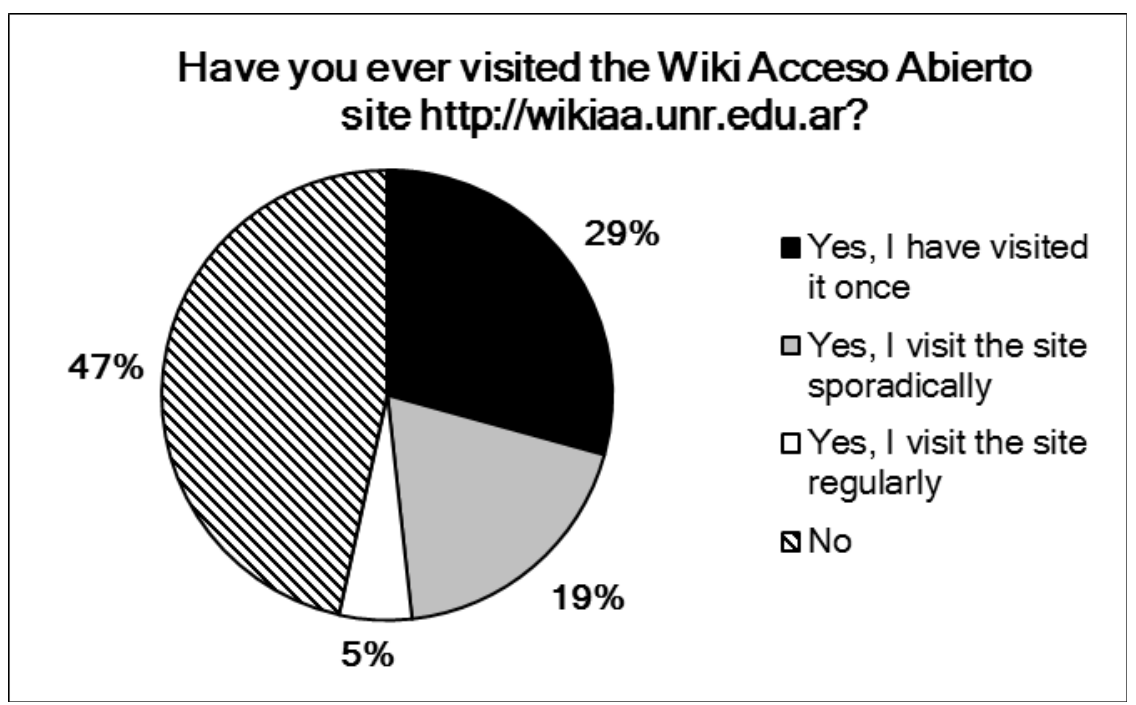

Figure 4: Visits to Wiki Acceso Abierto

One question sought to find out whether respondents had contributed content to the site. The percentage of those who said they contributed content was very small (9\%), the remaining 91\% replied that they had not contributed content, while two respondents omitted the answer to this question.

The reasons reported by respondents for not collaborating with the Wiki were lack of time (25 respondents), not having content to add (14 respondents), and only one respondent had difficulty to manage the MediaWiki software. Other reasons given for not contributing content were: unawareness of its existence (6 respondents); personal interest without the opportunity of professional application (1 respondent); and a lack of integration with existing systems ( 1 respondent). There were eight respondents who did not answer this question.

Knowing that, for the time being, Wiki AA has failed to become a collaborative venture, respondents were asked about the possibility of creating an editorial board for content on the site. Specifically, they were asked if they would join such a committee and most respondents (86.5\%) said they would. However, there was a $13.5 \%$ negative response out of the fifty responses to this question.

\section{Conclusion}

The region is mobilized, working and learning about access to knowledge and its implications. This is evidenced through the several established and ongoing regional collaborative projects that working in this area of the profession. Latin 
America is moving forward and becoming a leading force behind access to knowledge. The conflict between access to knowledge and intellectual property regulations, and its implications for implementing OA routes are shown as a concern within the Latin American library community that is driving this initiative in the region.

Starting from this point of view and interpreting the data from the countries that have been examined, it is possible to arrive at some conclusions for each country. For each of the countries that were studied the major achievements are highlighted below.

With respect to Chile, its major achivements are:

- Digital Rights NGO which seeks to reduce current barriers with regard to IP;

- Adoption of Creative Commons licenses;

- Provision of training to intermediaries and librarians;

- Provision of materials to raise awareness and show existing methods of releasing information; and its

- Study of the management of publicly funded information which is remarkable, as this initiative is an indication that these issues are growing in importance and weight within the government.

In terms of Brazil, , its major achivements are:

- Strong progress along the golden route;

- Tripling of the number of available electronic journals in the SEER portal;

- Pragmatic approach to advance along the road as quickly as possible, despite the slow progress of the bill that would allow for a more rapid growth of the green road and the loading of content into repositories; and

- Work on a local OA portal that can harvest content from journals and repositories.

With regard to Argentina, this country is

- Actively working at the level of government;

- Taking advantage of its growth potential, after a period of activity that was lagging behind the other two countries; and

- Ensuring that both OA initiatives (green and gold) are progressing in parallel, getting in tune, and working hard to have a worthy place among the other countries in the region. 
The information policies of institutions are the focus of interest for most librarians on the LLAAR list. Government policies are also emerging. It is also necessary to generate clear policies within institutions, where mandates seem to be the tool that have worked best and will release large amounts of scientific, technical and other information. On the other hand, evidence shows that Wiki AA is not as yet a mature collaborative endeavor in Latin American information communities. The survey results, however, offer positive prospects and should an editorial committee be created, this would result in the effective management of content.

The regional projects and collaborative endeavors have the promise of generating the best possibilities. The relative degree of success of OA initiatives will depend on the capabilities of research institutions and regional governments to implement effective OA policies. In this regard, the Federated Network of Institutional Repositories Scientific Documentation in Latin America Project is generating the most expectation because it has partnered with governmental institutions that are responsible for moving forward the proposal. However, changes in government could cause a change in governmental priorities which would in turn impact negatively on the agendas of the projects.

Another important issue would be whether Latin American projects can manage to integrate with international networks like COAR, which would facilitate taking advantage of experiences and global standards of scientific communication. In this sense, a key concept to consider is that of replicability, which is essential to the success of regional and international projects. This means ensuring that best practices are implemented in existing projects and used in newly created projects. It is certain that communicating, sharing and learning about the different realities of the region would help in the solution of problems and also assist in the development of strategies to face new challenges. The LLAAR mailing list is playing a vital role by demonstrating that informal communication is most effective and contributes to OA discussions. Cooperative and sustained growth in OA will make regional scientific production available and more visible. Besides, such cooperation will make it easier to find experts in different fields. Ongoing collaboration will help to strengthen and improve equal access to knowledge throughout the region. Moreover, progress in regional projects encourages the building of new citation metrics and use of available information. This would lead to new mechanisms for evaluating scientific production at the regional level. Tools like Intelligo will help in this regard.

While the policies that promote $\mathrm{OA}$ at a regional level are a key to progress, if the strategy is to further OA to knowledge, it is vital that the needs of investigators, as the main drivers of change, are considered. Research suggests that the relationship between institutional repositories and researchers, as producers and users, is far from being a close one (Russell and Day 2010). It is 
also essential that there is collaboration with researchers in order to facilitate processes and add value by integrating OA repositories into their daily work. Also necessary is expediting the interaction of researchers with the systems they use to manage their scientific production for different purposes, such as curriculum, institutional assessments, project presentations and personal page generation automatic updates. As Christine Borgman clearly states: "It is imperative that we understand more about the behavior and practice of individual scholars and learners, how they collaborate in distributed environments, and how they can take advantage of new capabilities, along with their reasons for doing so" (Borgman 2007).

Latin American countries can and should learn from the experience of other countries and projects that have experience in working on strategies which are concerned with moving OA to knowledge at different levels. At the macro level, solid policies, international standards and best practices should be adopted. At the micro level, work needs to be done with researchers in order to understand and integrate their needs into A2K strategies. The most promising possibility is to collaborate and share in order to advance regionally.

\section{References}

Argentina. Honorable Cámara de Diputados de la Nación. Proyecto de Ley 1927-D-2011. Creación de Repositorios Digitales Institucionales de Acceso Abierto, Propios o Compartidos. 2011.

http://revista.ibict.br/liinc/index.php/liinc/article/view/269. [Mar. 2011].

Alperin, J. P., Fischman, G. and Willinsky, J. "Open access and scholarly publishing in Latin America: ten flavours and a few reflections.” Liinc em Revista, 4.2 (2008). http://revista.ibict.br/liinc/index.php/liinc/article/view/269

Salvador Declaration on Open Access. 2005. www.icml9.org/meetings/openaccess/public/documents/declaration.htm [Mar. 2011].

Balkin, J. “Foreword.” Shaver, L. B. and Rizk, N. Access to Knowledge in Egypt: New Research on Intellectual Property, Innovation and Development. London: Bloomsbury Academic, 2010.

Banco Interamericano de Desarrollo. Estrategia Regional y Marco Interoperabilidad y Gestión para una Red Federada Latinoamericana de Repositorios de Rocumentación Científica. 2010.

www.iadb.org/projects/project.cfm?lang=es\&artid=-1\&project=rgt1684\&query=\&id=rg-t1684 [Mar. 2011].

Benkler, Y. The Wealth of Networks: How Social Production Transforms Markets and Freedom. New Haven, Conn.: Yale U P, 2006.

Bindé, J. and Matsuura, K. Towards Knowledge Societies. Paris: UNESCO, 2005. (UNESCO world report, 1).

Björk B-C, et al. "Open Access to the Scientific Journal Literature: Situation 2009.” PLoS ONE, 5. 6: e11273. 2010. http://dx.doi.org/10.1371/journal.pone.0011273 [Mar. 2011].

Borgman, C. L. Scholarship in the Digital Age: Information, Infrastructure, and the Internet. Cambridge, Mass.: MIT Press, 2007. 
Brasil. Câmara dos Deputados Projecto de Lei No 1.120. (Do Sr. Rodrigo Rollemberg). Dispõe sobre o Processo de Disseminação da Produção Décnico-científica pelas instituições de Ensino Superior no Brasil e dá Outras Providências. 2007.

http://kuramoto.files.wordpress.com/2010/08/parecer_deputado_ariosto_holanda.pdf [Mar. 2011].

Brasil. Senado Federal Projeto de Lei No 387 de 2011. Dispõe sobre o Processo de Registro e Disseminação da Produção Técnico-científica pelas Instituições de Educação Superior, bem como as Unidades de Pesquisa no Brasil e dá Outras Providências. 2011. http://legis.senado.gov.br/mate-pdf/93063.pdf [Mar. 2011].

Budapest Open Access Initiative. 2000. www.soros.org/openaccess [Mar. 2011].

Calver, M. C. and Stuart, B. J. "Patterns of Citations of Open Access and Non-Open Access Conservation Biology Journal and Book Chapters.” Conservation Biology, 24.3 (2010): 872-880.

Canessa, E. and Zennaro, M., eds. Science Dissemination Using Open Access: A Compendium of Selected Literature on Open Access. Trieste: Abdus Salam International Centre for Theoretical Physics, 2008.

Davis, P. M., et al. "Open access publishing, article downloads, and citations: randomised controlled trial.” BMJ (2008): 337:a568.

Fernández-Molina, J. C. and Guimarães, J. A. C. "The WIPO development agenda and the contribution of the international library community.” The Electronic Library, 27.6 (2009): 1010-1025.

Fernández Molina, J. C. and Chaves Guimarães, J. A. (2010) "Excepciones al derecho de autor en beneficio de las bibliotecas: situación de América Latina y el Caribe.” IFLA General Conference, Gothenburg, 2010. 76th Conference Proceedings. 2010. http://www.ifla.org/files/hq/papers/ifla76/121-molina-es.pdf [Mar. 2011].

Gargouri Y., et al. "Self-Selected or Mandated, Open Access Increases Citation Impact for Higher Quality Research”. PLoS ONE, 5.10 (2010): e13636. 2010.

www.plosone.org/article/info\%3Adoi\%2F10.1371\%2Fjournal.pone.0013636 [Mar. 2011].

Geneva Declaration on the Future of the World Intellectual Property Organization. 2004. http://www.cptech.org/ip/wipo/futureofwipodeclaration.pdf [Mar. 2011].

Gómez, N., et al. "Open access indicators and information society: the Latin American case.” OCLC Systems and Services, 25.2 (2009): 82-92.

Gómez Dueñas, L. F. "Repositorios documentales y la iniciativa de archivos abiertos en Latinoamérica.” BiD: Textos Universitaris de Biblioteconomia i Documentació, June 20 (2008). http://www.ub.edu/bid/20gomez2.htm [Mar. 2011].

Guédon, J. "Open Access and the divide between "mainstream” and "peripheral” science." Ferreira, Sueli Mara S. P. and Targino, Maria das Graças, eds. Como Gerir e Qualificar Revistas Científicas. [2007]. http://eprints.rclis.org/archive/00012156/ [Mar. 2011].

Hajjem, C. and Harnad, S. Citation Advantage for OA Self-Archiving Is Independent of Journal Impact Factor, Article Age, and Number of Co-Authors. Southampton: University of Southampton, Electronics and Computer Science. [2007]. http://eprints.ecs.soton.ac.uk/11688/ [Mar. 2011].

Hajjem, C., Harnad S. and Gingras, Y. "Ten-Year Cross-Disciplinary Comparison of the Growth of Open Access and How it Increases Research Citation Impact.” IEEE Data Engineering Bulletin, 28 (2005): 39-47.

Harnad, S. "Open Access to Research: Changing Researcher Behavior through University and Funder Mandates.” EDEM2010: Proceedings of the 4th International Conference 
on E-Democracy. [2010]. http://eprints.ecs.soton.ac.uk/22401/1/harnad-jedem.pdf [Mar. 2011].

Harnad, S., et al. "The Access/Impact Problem and the Green and Gold Roads to Open Access.” Serials Review, 30.4 (2004): 310-314.

-. "The Access/Impact Problem and the Green and Gold Roads to Open Access: An Update.” Serials Review, 34.1, (2008): 36-40.

IBICIT. Manifesto Brasileiro de apoio ao Acesso Livre à Informação Científica. 2005. www.rnp.br/noticias/imprensa/2005/not-imp-050914b.html [Mar. 2011].

Kapczynski, A. "The Access to Knowledge Mobilization and the New Politics of Intellectual Property.” The Yale Law Journal, 117.5 (2008): 804-885.

Lawrence, S. “Online or Invisible?” Nature, 411.6837 (2001): 521.

Leite, F. C. L. Como Cerenciar e Ampliar a Visibilidade da Informação Científica Brasileira: Repositórios Institucionais de Acesso Aberto. IBICT. 2009.

www.ibict.br/anexos_noticias/repositorios.institucionais.F.Leite_atualizado.pdf [Mar. 2011].

McKay, D. "Institutional repositories and their 'other' users: usability beyond authors." ARIADNE, 52. 2007. www.ariadne.ac.uk/issue52/mckay/ [Mar. 2011].

Moed, H. F. "The effect of 'open access' upon citation impact: an analysis of ArXiv's condensed matter section.” Journal of the American Society for Information Science and Technology, 58 (2007): 2047-2054.

Morrison, H. "The Dramatic Growth of Open Access: Implications and Opportunities for Resource Sharing.” Journal of Interlibrary Loan, Document Delivery and Electronic Reserve, 16. 3 (2006): 95-107.

Norris, M., Oppenheim, C. and Rowland, F. "The Citation Advantage of Open-Access Articles.” Journal of the American Society for Information Science and Technology, 59 (2008): 1963-1972.

Packer, A. L. and Meneghini, R. "Learning to communicate science in developing countries.” Interciencia Caracas, 32.9 (2007): 643-647.

Pessach, G. (2007) "The Role of Libraries in A2K: Taking Stock and Looking Ahead.” Michigan State DCL Law Review, 1 (2007): 257-270.

Pontificia Universidad Católica de Valparaíso. Directorio de Revistas Open Access reconocidas por el ISI Web of Science. [2009]. www.ejbiotechnology.cl/proyecto/index.php [Mar. 2011].

Pulido O. D., Robledo M. R. and Agudelo, C. A. "Scientific writing, scientific communication and open access: An international, multidisciplinary project - NECOBELAC. [Escritura, Comunicación Científica y Acceso Abierto: Un Proyecto Internacional y Multidisciplinario-NECOBELAC]”. Revista de Salud Publica, 11.2 (2009): 310-314.

Rodríguez Gallardo, A. "Visibilidad de la ciencia latinoamericana: un reto para la bibliotecología y la información en la región por más de 35 años.” IFLA General Conference. 76th Conference Proceedings. [2010]. http://www.ifla.org/files/hq/papers/ifla76/121gallardo-es.pdf [Mar. 2011].

Russell, R. and Day, M. "Institutional Repository Interaction with Research Users: A Review of Current Practice.” New Review of Academic Librarianship, 16.1 (2010): 116131.

Santillán-Aldana, J. “OJS en América Latina.” I Encontro Nacional de Usuários do SEER, Florianópolis, Brazil, 14 - 16 Jul, 2010. 2010.

http://eprints.rclis.org/18893/1/ojs_america_latina.pdf [Mar. 2011]. 
SCImago. SJR - SCImago Journal \& Country Rank. http://www.scimagojr.com [Aug. 2011].

Shaver, L. "Defining and Measuring Access to Knowledge: Towards an A2K Index.” I/S: Journal of Law and Policy for the Information Society, 4.2. [2008]. http://digitalcommons.law.yale.edu/cgi/viewcontent.cgi?article=1021\&context=fss_pa pers [Mar. 2011].

Stiglitz, J. "Knowledge as a global public good.” Kaul, I., Grunberg, I. and Stern, M., eds. Global Public Goods: International Cooperation in the 21st Century. New York: Oxford University Press, [1999].

Suber, P. and Arunachalam, S. “Open Access to Science in the Developing World.” WorldInformation City, October 17. Tunis: WSIS, [2005].

Swan, A. “The culture of Open Access: researchers' views and responses.” Jacobs, N., ed. Open Access: Key Strategic, Technical and Economic Aspects. Oxford: Chandos, 2006.

-. "Why Open Access for Brazil?” (Por que acesso livre no Brazil?)” Liinc em Revista, 4.2 (2008). Special Issue: Acesso Livre: um novo paradigma para a comunicação científica. [2008]. http://revista.ibict.br/liinc/index.php/liinc/article/view/279/166 [Mar. 2011].

Tapscott, D. and Williams, A. D. Wikinomics: How Mass Collaboration Changes Everything. New York: Portfolio, [2006].

Tise, E. R., Raju, R. and Masango, C. "Libraries Driving Access to Knowledge: a discussion paper”. IFLA Journal, 34.4 (2008): 341-346.

UNESCO. German Commission for UNESCO. Open Access: Opportunities and Challenges: A Handbook. Brussels: European Commission, Directorate General for Research, [2008].

Verschraegen, G. and Schiltz, M. "Knowledge as a Global Public Good: The Role and Importance of Open Access.” Societies Without Borders, 2.2 (2007): 157-174.

UNESCO. Greenstone: Un Software Libre de Código Abierto para la Construcción de Bibliotecas Digitales: Experiencias en América Latina y el Caribe. Günther Cyranek, ed. [2010]. http://unesdoc.unesco.org/images/0018/001887/188719s.pdf [Mar. 2011].

Universidad Nacional de Córdoba. Secretaría de Asuntos Académicos. Resolución 116/2010. Resolución sobre Publicaciones Universitarias de Acceso Abierto. 2010. www.academica.unc.edu.ar/informacionsobre/normativas/documentos/Resolucion\%20OCW.pdf/view [Mar. 2011]. 